\title{
Studies on the Mechanism of Xylitol-induced Insulin Secretion in Dogs
}

\author{
Effect of its Infusion into the Pancreatic Artery, and the Inhibition by Epinephrine and Diazoxide of Xylitol- \\ induced Hyperinsulinaemia
}

\author{
Takeshi KuzUYa and Yasunori KanazaWA*
}

The Third Department of Internal Medicine, Faculty of Medicine, University of Tokyo. Hongo, Tokyo, Japan

Received: November 4, 1968

Summary. The effect of infusion of small doses of xylitol into the pancreatic artery upon insulin release was studied in anaesthetized dogs, in order to decide whether the strong insulin-releasing effect of xylitol in dogs is mediated by a direct action of xylitol upon the islets or indirectly by some of its metabolites. Xylitol or glucose was infused at $0.5-1.0 \mathrm{mg} / \mathrm{kg} \cdot \mathrm{min}$ either into the femoral vein or into the superior pancreaticoduodenal artery, and the changes in plasma insulin were measured in the superior pancreaticoduodenal vein. Infusion into the pancreatic artery always resulted in a sharp increase in insulin release, whereas intravenous infusion caused no or little increase. Infusion of xylitol into the superior pancreaticoduodenal artery produced a prompt increase in plasma insulin in the superior pancreaticoduodenal vein but not in the splenic vein. These data suggest that xylitol has a direct stimulatory effect upon islet cells. During intravenous infusion of epinephrine $(1.0 \mu \mathrm{g} / \mathrm{kg}$. min), plasma insulin did not increase despite intravenous administration of glucose or xylitol $(0.4 \mathrm{~g} / \mathrm{kg})$. There was a rebound rise of plasma insulin after cessation of epinephrine infusion. Plasma insulin responses to intravenous injection of glucose or xylitol $(0.4 \mathrm{~g} / \mathrm{kg})$ were inhibited also by the intravenous infusion of diazoxide $(0.2 \mathrm{mg} / \mathrm{kg} \cdot \mathrm{min})$, but this was somewhat variable among individual dogs. The suppression by epinephrine or diazoxide of both glucose- and xylitol-induced hyperinsulinaemia may suggest that there is some common mechanism between the insulin-releasing effects of glucose and xylitol.

Etudes sur le mécanisme de la sécrétion d'insuline provoquée par le xylitol chez des chiens. Elffet de son infusion dans l'artère pancréatique, et inhibition par l'adrénaline et le diazoxide de l'hyperinsulinémie provoquée par le xylitol

Résumé. L'effet sur la sécrétion d'insuline de l'infusion de petites doses de xylitol dans l'artère pancréatique a été étudié chez des chiens anesthésiés, afin de savoir si l'effet fortement insulino-sécréteur du xylitol chez les chiens est dû à une action directe du xylitol sur les îlots ou à une action indirecte par l'intermédiaire de certains de ses métabolites. Le xylitol ou le glucose était infusé à la dose de $0.5-1.0 \mathrm{mg} / \mathrm{kg}$. min, soit dans la veine fémorale, soit dans l'artère pancréatico-duodénale supérieure, et les variations de l'insuline plasmatique étaient mesurées dans la veine pancréatico-duodénalo supérieure. L'infusion dans l'artère pancréatique provoquait toujours une rapide augmentation de la sécrétion d'insuline, tandis que l'infusion intraveineuse ne causait pas ou peu d'augmentation. L'infusion de xylitol dans l'artère pancréaticoduodénale supérieure provoquait une augmentation

* Present address: Institut de Biochimie Clinique, Université de Genève, Sentier de la Roseraie, CH.1211 Genève 4, Suisse. prompte de l'insuline plasmatique dans la veine pancréatico-duodénale supérieure, mais pas dans la veine splénique. Ces données suggèrent que le xylitol a un effet stimulateur direct sur les cellules des îlots. - Pendant l'infusion intraveineuse d'adrénaline $(1.0 \mu \mathrm{g} / \mathrm{kg}$. $\mathrm{min})$, l'insuline plasmatique n'augmentait pas malgré l'administration intraveineuse de glucose ou de xylitol $(0.4 \mathrm{~g} / \mathrm{kg})$. Après l'arrêt de l'infusion d'adrénaline, l'insuline plasmatique présentait un phénomène de rebound. Less réponses de l'insuline plasmatique à l'injection intraveineuse de glucose ou de xylitol $(0.4 \mathrm{~g} / \mathrm{kg})$ étaient également inhibées par l'infusion intraveineuse de diazoxide $(0.2 \mathrm{mg} /$ kg. min), mais ceci était un peu variable selon les chiens. La suppression par l'adrénaline ou le diazoxide de l'hyperinsulinémie provoquée par le glucose et le xylitol peut suggérer qu'il existe un mécanisme commun entre les effets insulino-sécréteurs du glucose et du xylitol.

Untersuchungen zum Mechanismus der verstärkten Insulinselkretion unter $X y l i t$. Effekte seiner Infusion in die Pankreasarterie und Hemmung der Xylit-bedingten Hyperinsulinaemie durch Adrenalin und Diazoxid

Zusammenfassung. An anaesthesierten Hunden wurde die Wirkung der Infusion kleiner Xylit-Mengen in die Pankreasarterie auf die Insulinfreisetzung untersucht, um zu klären, ob das Xylit direkt oder über einen seiner Metabolite auf die Insulinausschüttung wirkt. Xylit oder Glucose wurde in Mengen von $0.5-1.0 \mathrm{mg} / \mathrm{kg} / \mathrm{min}$ entweder in die Femoralvene oder in die A.pankreaticoduodenalis sup. infundiert und die Änderung des PlasmaInsulins in der V.pankreatico-duodenalis sup. gemessen. Zufuhr über die Pankreasarterie löste immer eine abrupte Steigerung der Insulinfreisetzung aus, während intravenöse Gaben zu keinem oder nur einem geringen Anstieg führten. Die Xylit-Infusion in die A.pankreaticoduodenalis sup.bewirkte zwar eine prompte Steigerung der Plasma-Insulinspiegel in der V.pankreatico duodenalis sup., nicht aber in der Milzvene: - Diese Befunde sprechen dafür, daß Xylit die Inselzellen direkt stimuliert. Während einer i.v.Infusion von $1.0 \mu \mathrm{g} / \mathrm{kg} / \mathrm{min}$ Adrenalin stieg das Plasma-Insulin trotz intravenöser Zufuhr von $0.4 \mathrm{~g} / \mathrm{kg}$ Glucose oder Xylit nicht an. Nach Beendigung der Adrenalin-Infusion wurde ein verstärIkter Wiederanstieg des Plasma-Insulins beobachtet. Auch durch i.v.Gaben von $0.2 \mathrm{mg} / \mathrm{kg} / \mathrm{min}$ Diazoxid ließ sich die Wirkung der Infusion von $0.4 \mathrm{~g} / \mathrm{kg}$ Glucose oder Xylit unterdrükken, wobei sich jedoch Unterschiede zwischen den einzelnen Tieren ergaben. Die Aufhebung des Xylit- u. Glucose-Effektes auf die Insulinsekretion durch Adrenalin und Diazoxid könnte darauf hinweisen, daß die Steigerung der Insulinfreisetzung durch Glucose und Xylit auf einem gemeinsamen Mechanismus beruht.

Key-words: Insulin secretion, local vs. systemic infusions, glueose, xylitol, epinephrine, diazoxide. 


\section{Introduction}

Striking xylitol-induced hyperinsulinaemia in dogs was first reported by Hirata et al. [5] and by us [8]. Our previous study disclosed that this effect of xylitol in dogs becomes more pronounced with higher doses, and that xylitol is more effective than glucose, even when administered orally [9]. It is likely that the hyperinsulinaemia results from augmented secretion of insulin from the pancreas, because plasma insulin concentration in the pancreatic vein promptly increased after intravenous injection of xylitol, paralleling that in the peripheral vein [9]. It was suggested that some metabolic processes or intermediates which are com. mon to both glucose and xylitol may be directly related to the mechanism of insulin secretion.

However, it is not yet certain whether xylitol itself acts directly upon the islets or whether insulin secretion is stimulated by a metabolite. Consequently, we have investigated the effect of infusion into the pancreatic artery of a small dose of xylitol previously shown to be ineffective when used systemically. Furthermore, the inhibitory effects of epinephrine [12] and diazoxide [4] upon xylitol-induced insulin secretion were also studied.

\section{Animals.}

\section{Methods}

Adult dogs of mixed breed of $7-15 \mathrm{~kg}$ were fed a controlled diet for at least one week, and subjected to the experiment after an overnight fast.

Infusions of glucose and xylitol into the superior pancreaticoduodenal artery. Dogs were anaesthetized with intravenous sodium pentobarbital $(25-30 \mathrm{mg} / \mathrm{kg})$, and laparotomized in supine position. The superior pancreaticoduodenal vessels were severed from the surrounding tissue, and the branching points of the right gastroepiploic vessels were exposed. A Teflon catheter ( $2 \mathrm{~mm}$ in diameter) was inserted into the right gastroepiploic vein, and its tip placed just beyond the junction of this vessel with the superior pancreaticoduodenal vein (Fig. 1). Then a Teflon catheter ( $1 \mathrm{~mm}$ in diameter) was inserted into the right gastroepiploic artery and threaded upstream to reach the superior pancreaticoduodenal artery. The main duodenal branches of the superior pancreaticoduodenal vessels were ligated to minimize the extrapancreatic distribution of the infused substance and the dilution of secreted insulin by the blood coming from the duodenum. These procedures usually took about one hour. Collection of the first blood sample was begun $60-90$ min after the end of these procedures. Blood samples were withdrawn from the femoral artery by an in. dwelling needle and from the pancreaticoduodenal vein by the catheter described above. Both the arterial needle and the pancreatic vein catheter were filled with heparinized saline $(10 \mathrm{U} / \mathrm{ml})$ after each blood sampling. Heparinized saline was constantly infused at a rate of $25-50 \mathrm{ml} / \mathrm{h}$ through the pancreatic artery catheter to keep it patent. Glucose or xylitol was in- fused either through this catheter or into the femoral vein for $15-30 \mathrm{~min}$ in a dose of $0.5-1 \mathrm{mg} / \mathrm{kg}$. $\mathrm{min}$, with a constant rate of $50 \mathrm{ml} / \mathrm{h}$ with the help of an infusion pump. Successive infusions were given after intervals of at least $60 \mathrm{~min}$.

In one experiment, splenectomy was performed and an additional catheter was inserted into the splenic vein. The tip of this catheter was placed about $1 \mathrm{~cm}$

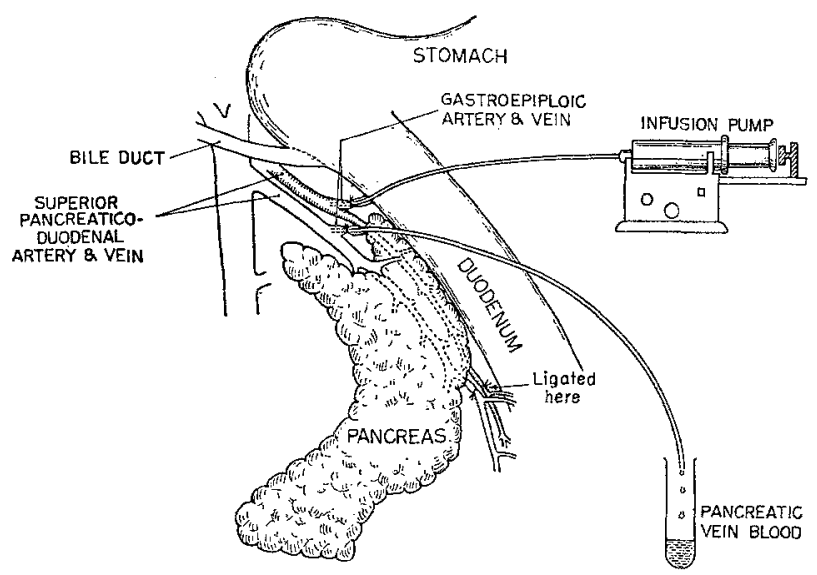

Fig. 1. Diagram of catheterizations into the superior pancreaticoduodenal artery and vein. The catheters were inserted through the right gastroepiploic vessels

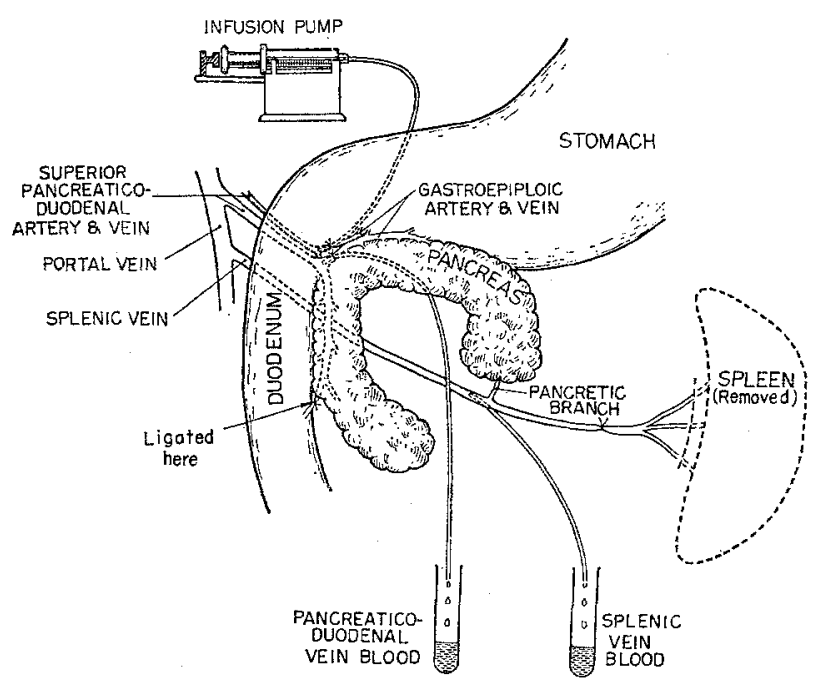

Fig. 2. Diagram of blood sampling from the superior pancreaticoduodenal vein and the splenic vein. In addition to catheterizations into the superior pancreaticoduodenal artery and vein, a catheter was inserted into the splenic vein after splenectomy

downstream from the site where the last pancreatic branch was flowing in. Glucose and xylitol, $0.5 \mathrm{mg} / \mathrm{kg}$. $\mathrm{min}$, were infused into the superior pancreaticoduodenal artery, and blood was withdrawn simultaneously from the femoral artery, superior pancreaticoduodenal vein and splenic vein (Fig. 2).

Effect of infusion of epinephrine and diazoxide upon xylitol- or glucose-induced hyperinsulinaemia. Dogs were anaesthetized with sodium pentobarbital and kept su- 
pine. About 90 min after anaesthesia, three control blood samples were withdrawn from the femoral vein at $15 \mathrm{~min}$ intervals. Constant infusion of epinephrine (1 $\mu \mathrm{g} / \mathrm{kg} . \mathrm{min}$ ) into the femoral vein at $25-50 \mathrm{ml} /$ $60 \mathrm{~min}$ was then started and continued for $60 \mathrm{~min}$. Glucose or xylitol, $0.4 \mathrm{~g} / \mathrm{kg}$, was injected as $20 \%$ solution into the femoral vein over $10 \mathrm{~min}$ from the 20 th to the 30th min of epinephrine infusion. Blood samplings were carried out repeatedly during, and for $120 \mathrm{~min}$ after, the infusion of epinephrine. To prevent oxidation of epinephrine, it was diluted with saline containing $2 \mathrm{mg} / \mathrm{ml}$ ascorbic acid.

The diazoxide experiments were performed in the same way as the epinephrine experiments. Diazoxide $(100-150 \mathrm{mg})$ was dissolved in $100 \mathrm{ml}$ saline by gradual addition of $\mathrm{NaOH}$ and warming. The final $\mathrm{pH}$ was 10.5-11.0. This solution was infused into the femoral vein at $0.2 \mathrm{mg} / \mathrm{kg}$. min for $60 \mathrm{~min}$. Glucose or xylitol, $0.4 \mathrm{~g} / \mathrm{kg}$, was administered intravenously from the $20 \mathrm{th}$ to the 30 th $\mathrm{min}$ after diazoxide infusion was started.

Treatment of blood samples. Blood samples were centrifuged within one hour. Plasma was kept frozen at $-20^{\circ} \mathrm{C}$. Plasma glucose was determined by a glucoseoxidase method. Xylitol was measured by a periodate oxidation method [1] after deproteinization according to Somogri [14]. Plasma insulin was assayed by a double antibody radioimmunoassay using dog insulin standard [7].

\section{Results}

1. Infusions of small doses of glucose or xylitol into the femoral vein and into the pancreatic artery. In 2 dogs, glucose was infused at $1.0 \mathrm{mg} / \mathrm{kg} \cdot \min$ first into the femoral vein for $15 \mathrm{~min}$, then after an interval of one hour into the pancreaticoduodenal artery for $15 \mathrm{~min}$. In 2 other dogs, these two infusions were given in the reverse order (Table 1 ). The intravenous infusion of this small amount of glucose did not increase significantly in each case plasma glucose and insulin in the femoral artery and in the pancreatic vein. By contrast, infusion of glucose into the pancreaticoduodenal artery produced prompt increases of both glucose and insulin levels in the pancreatic vein, and also of insulin levels in the femoral artery. However, arterial glucose did not increase significantly. After cessation of in. fusion, plasma glucose in the pancreatic vein decreased promptly, returning to the control level within $15 \mathrm{~min}$, and insulin returned to the pre-infusion level within $30 \mathrm{~min}$. Five dogs received infusions of xylitol $(1.0 \mathrm{mg})$ $\mathrm{kg} \cdot \mathrm{min}$ ) into the femoral vein and into the pancreaticoduodenal artery, each for $15 \mathrm{~min}$, with an interval of one hour in between. Infusions were given first into the femoral vein and then into the pancreaticoduodenal artery in 3 dogs, and the order was reversed in 2 dogs (Table 2). Plasma glucose showed no significant change. Plasma xylitol and insulin levels in the femoral artery and pancreatic vein did not rise significantly after intravenous infusion of xylitol. During infusion into the pancreaticoduodenal artery, plasma xylitol in the pancreatic vein and plasma insulin in the femoral artery and pancreatic vein clearly increased, but the xylitol levels in the femoral artery did not increase. There were marked individual variations in the magnitude of the increases in glucose and xylitol concentrations in the pancreatic vein during infusion into the pancreaticoduodenal artery of these substances.
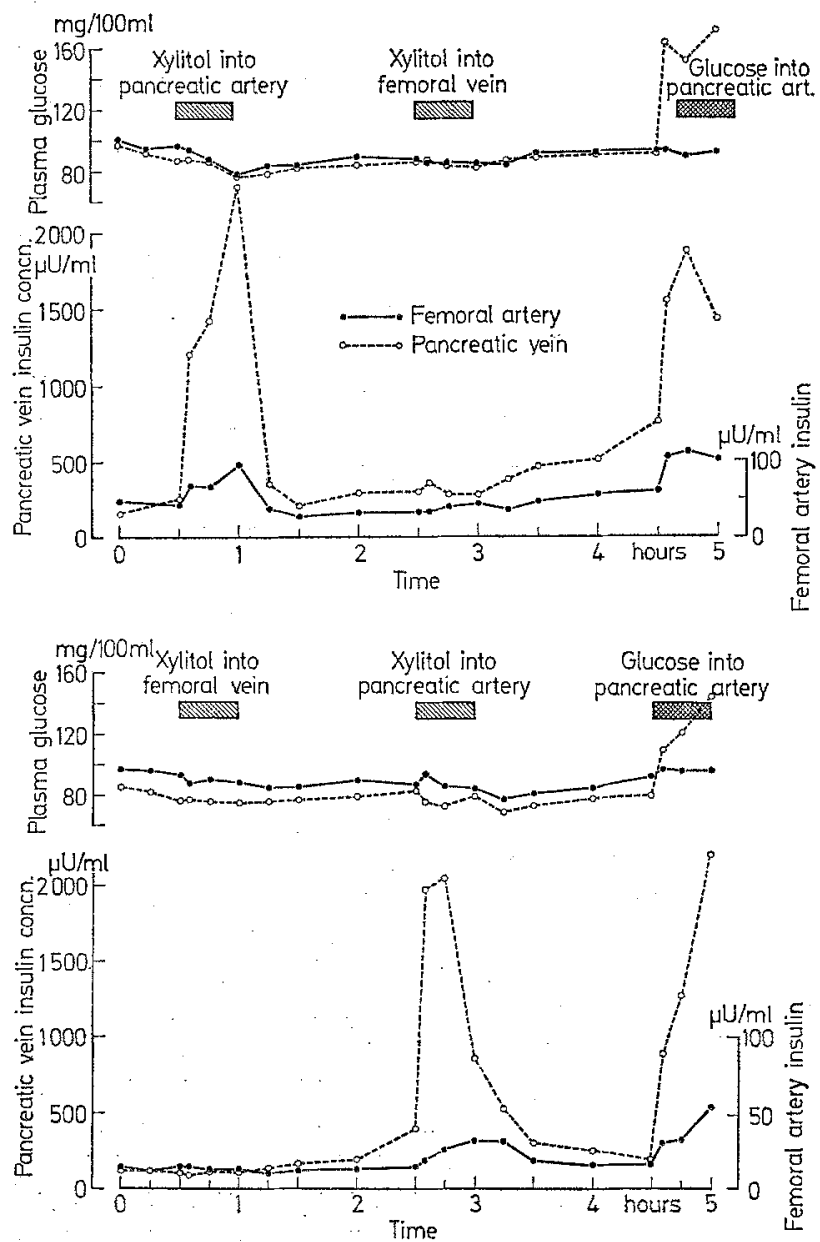

Fig. 3. Effect of the infusions of xylitol into the pancreatic artery and femoral vein and of glucose into the pancreatic artery upon plasma glucose and insulin concentrations in 2 dogs. Xylitol and glucose were infused at $0.5 \mathrm{mg} / \mathrm{kg} \cdot \mathrm{min}$ for $30 \mathrm{~min}$. Plasma insulin increased in the pancreatic vein and in the femoral artery when these substances were infused into the pancreatic artery, but remained unchanged by the systemic intravenous infusion of xylitol

Two experiments were carried out similarly, but with slower and more protracted $(0.5 \mathrm{mg} / \mathrm{kg}$. min over $30 \mathrm{~min}$ ) infusion. The results were similar (Fig. 3). Plasma insulin in the pancreatic vein and in the femoral artery did not change as a result of intravenous infusions of glucose or xylitol, but increased clearly when these substances were administered into the superior pancreaticoduodenal artery.

The results of an experiment in which blood was taken both from the superior pancreaticoduodenal vein and the splenic yein are presented in Fig. 4. During 
glucose or xylitol infusion into the superior pancreaticoduodenal artery, plasma glucose or xylitol concentration increased markedly in the superior pancreaticoduodenal vein, but did not rise in the femoral artery and in the splenic vein. Plasma insulin in the superior pancreaticoduodenal vein increased sharply during the infusions, but the insulin levels in the splenic vein did not show a clear increase.
Xylitol $(0.4 \mathrm{~g} / \mathrm{kg})$ was administered intravenously during the infusion of epinephrine in the same animals that received the infusion of epinephrine alone (Fig. 7). This dose usually produces a prompt and marked rise in plasma insulin [5, 8]. During epinephrine infusion, however, administration of xylitol did not cause any increase in plasma insulin. Plasma xylitol level and its disappearance curve were not significantly different
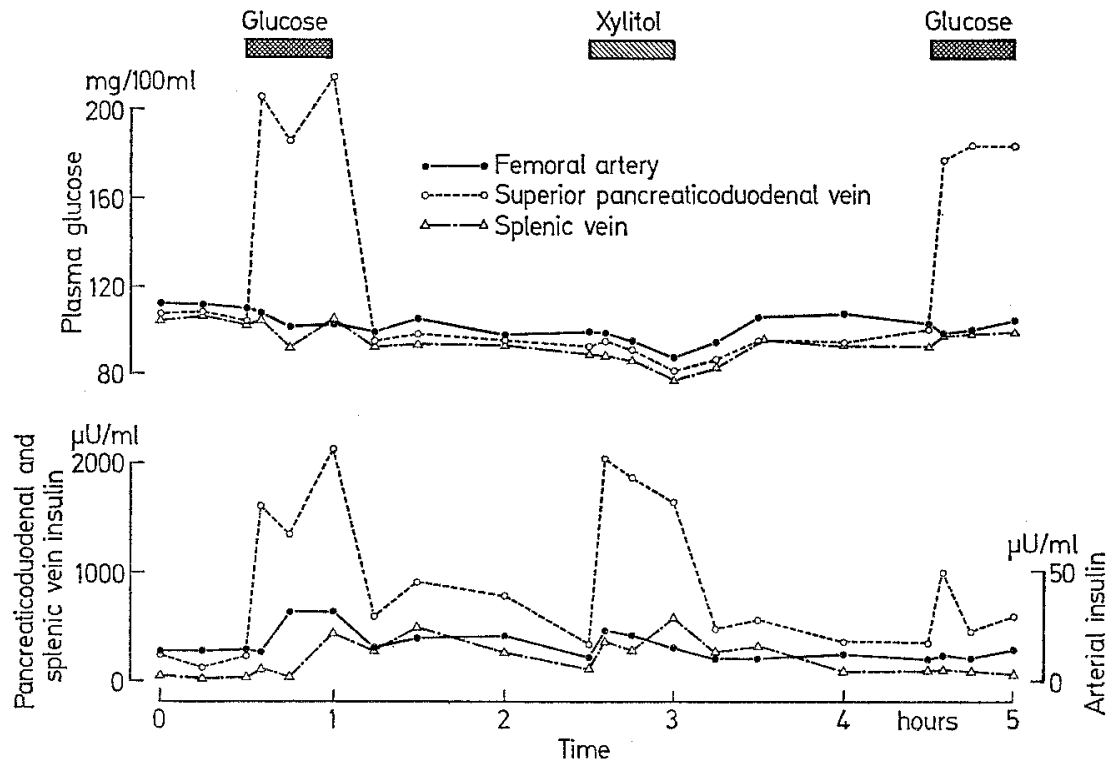

Fig. 4. Changes in plasma glucose and insulin in the femoral artery, superior pancreaticoduodenal vein and splenic vein during the infusions of glucose and xylitol into the superior pancreaticoduodenal artery. Plasma insulin in the superior pancreaticoduodenal vein increased promptly but plasma insulin in the splenic vein did not rise clearly

2. Effect of epinephrine infusion on glucose- or xylitol-induced hyperinsulinaemia

When epinephrine was infused at a rate of $1 \mu \mathrm{g} / \mathrm{kg}$. min, plasma glucose increased promptly and remained high throughout the infusion (Fig. 5). It tended to decrease 5-10 min after the end of the infusion, but the mean plasma glucose level was still higher than the preinfusion level, 2 hours after cessation of the infusion. During the infusion, plasma insulin did not increase at all despite marked hyperglycaemia, but following the cessation of infusion it rose promptly.

When glucose $(0.4 \mathrm{~g} / \mathrm{kg})$ was given intravenously during epinephrine infusion, plasma glucose reached $450-528 \mathrm{mg} / 100 \mathrm{ml}$, then gradually decreased (Fig. 6). Plasma insulin did not increase significantly during the infusion of epinephrine, but rose immediately after the end of infusion ${ }^{1}$.

1 Our control values for plasma insulin (mean of 5 dogs) at $0,10,20,30$, and $60 \mathrm{~min}$ after intravenous administration of glucose $(0.4 \mathrm{~g} / \mathrm{kg})$ were $65,68,51,35$, and $22 \mu \mathrm{U} / \mathrm{ml}$ respectively. Plasma insulin and xylitol levels (mean of 5 dogs) at $0,10,20,30$, and $60 \mathrm{~min}$ after intravenous administration of xylitol $(0.4 \mathrm{~g} / \mathrm{kg})$ were $111,188,167,118$ and $43 \mu \mathrm{C} / \mathrm{ml}$ for insulin [8] and $160,81,43,18$ and $9 \mathrm{mg} / 100 \mathrm{ml}$ for xylitol respectively. whether xylitol was given alone ${ }^{1}$ or during epinephrine infusion. Immediately after termination of epinephrine infusion, there was again a rebound rise of plasma insulin. When xylitol was administered, the elevated plasma glucose either decreased slightly or remained unchanged, despite no increase in plasma insulin. Plasma glucose remained elevated for about $30 \mathrm{~min}$ after the end of epinephrine infusion, then tended to decrease.

3. Effect of diazoxide infusion on glucose- or xylitolinduced hyperinsulinaemia.

In most cases, plasma glucose increased slightly after the infusion of diazoxide was started. The degree of hyperglycaemia produced during diazoxide infusion was variable among individual dogs. Following administration of glucose, plasma glucose reached the peak of $280-369 \mathrm{mg} / 100 \mathrm{ml}$ immediately, and decreased thereafter, but the glucose tolerance curve was much retarded (Fig. 8). Plasma insulin tended to decrease during diazoxide infusion, and remained low despite glucose loading in 4 dogs, but in one dog there was a prompt rise of plasma insulin after glucose injection. It is interesting that fairly good glucose to- 


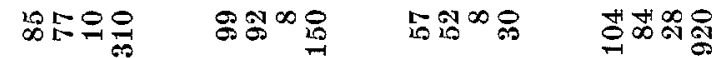

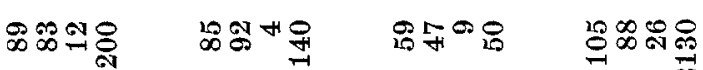

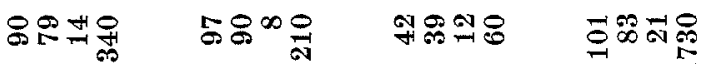

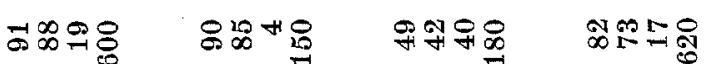

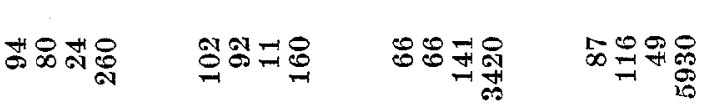

政

द्व

要

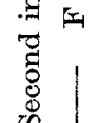

我点

$\sin \infty$

质

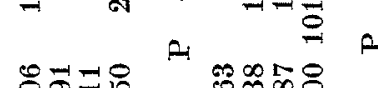

S.

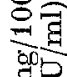

U2

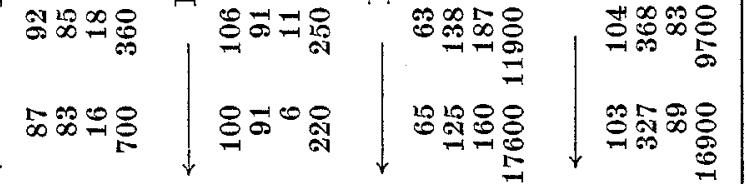

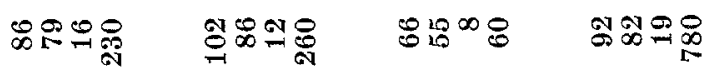

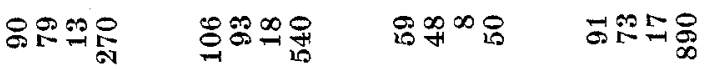

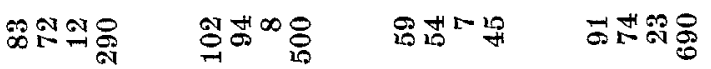

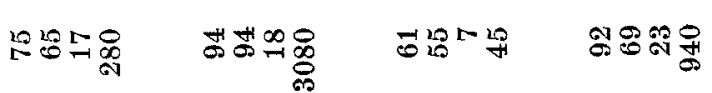

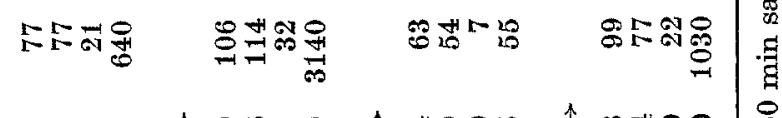

政

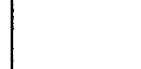

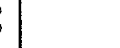

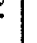

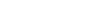

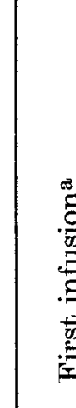

要.

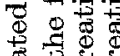

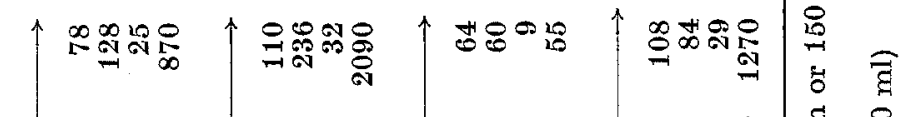

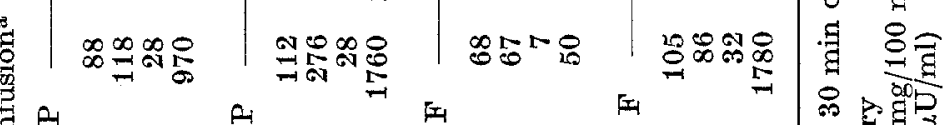

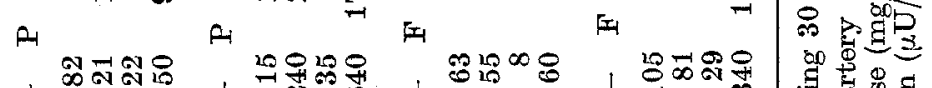

菁|

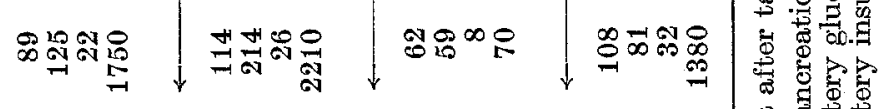

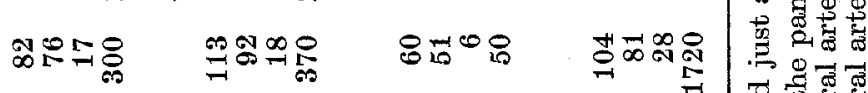

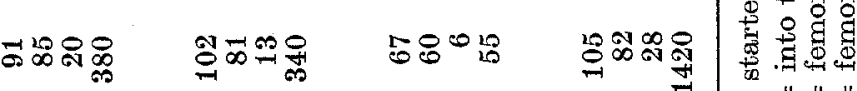

๓

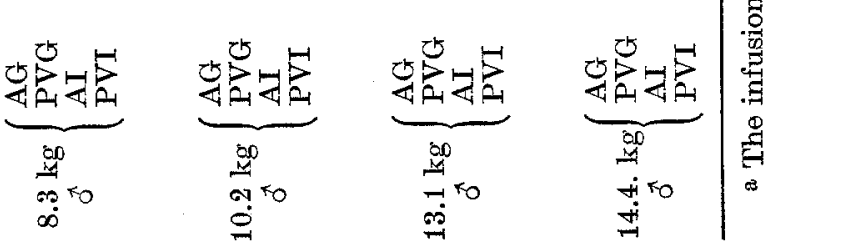




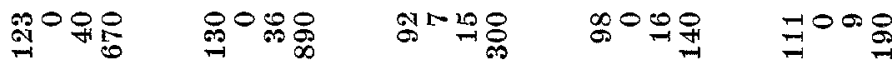

背1

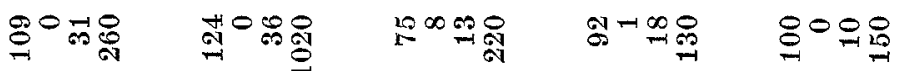

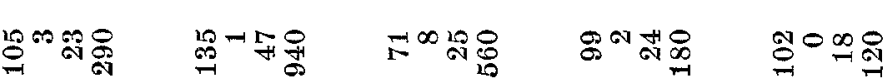

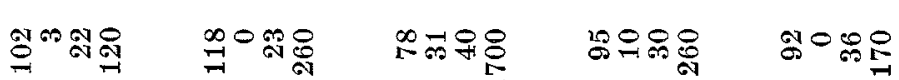

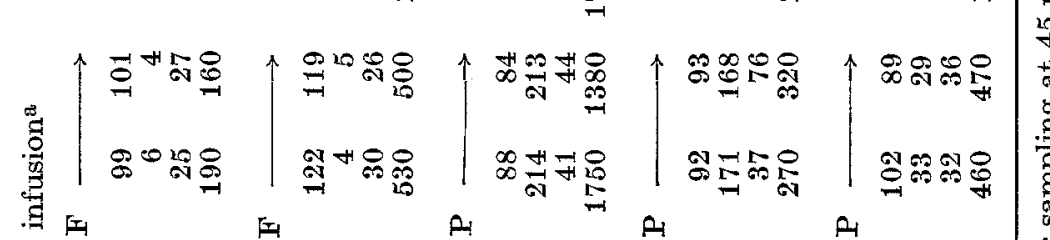

F A D

芴|

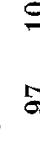

$\sin$

Ins

$8 \% \infty$

4008

Ar

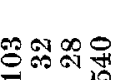

สิ

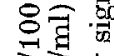

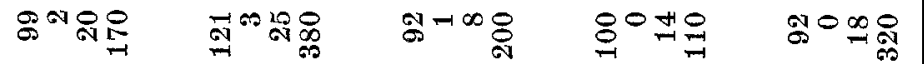

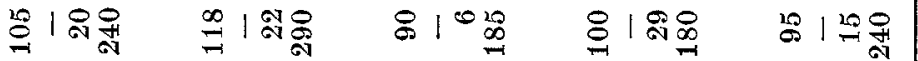

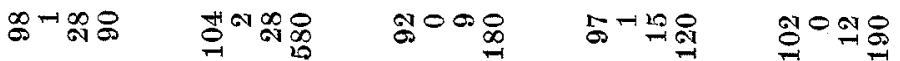

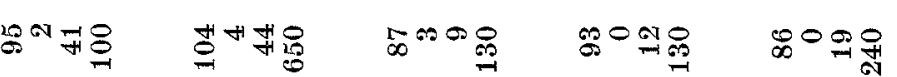

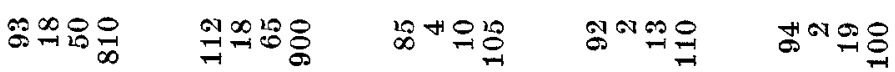

형

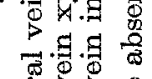

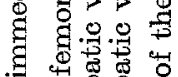

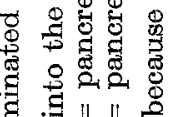

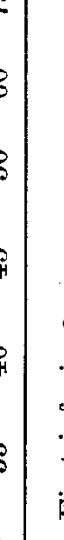

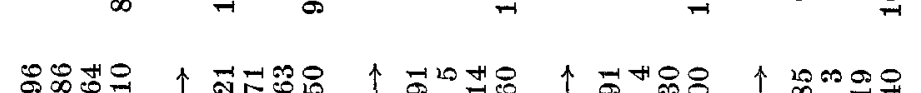

告

$8 R$

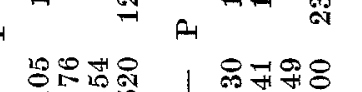

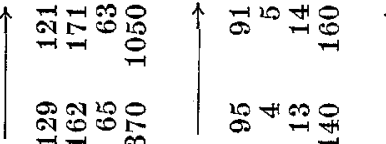

盾

$8+9$

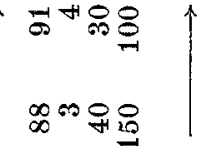

Ex

잉용

$\rightarrow$ สู

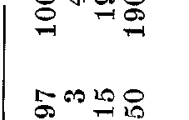

제용

$\operatorname{los}_{\infty}^{\infty} \rightarrow$

\&

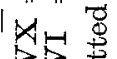

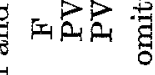

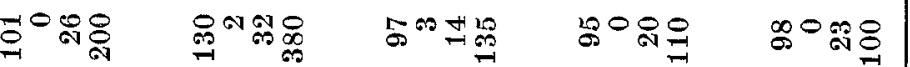

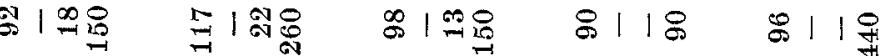

舟

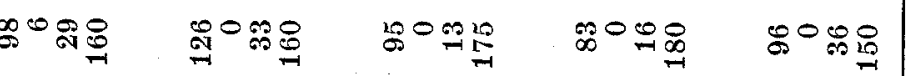

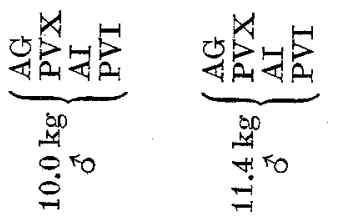

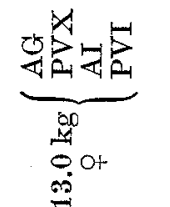

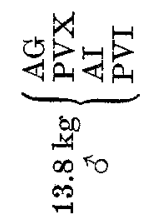

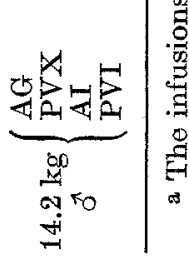


lerance was preserved in this dog. There was a tendency for a gradual increase of plasma insulin after termination of diazoxide infusion.

Plasma glucose continued to increase following xy- litol administration (Fig. 9). Despite the impaired glucose tolerance during diazoxide infusion, the changes in plasma xylitol were not significantly different from control experiments in which xylitol was given alone.
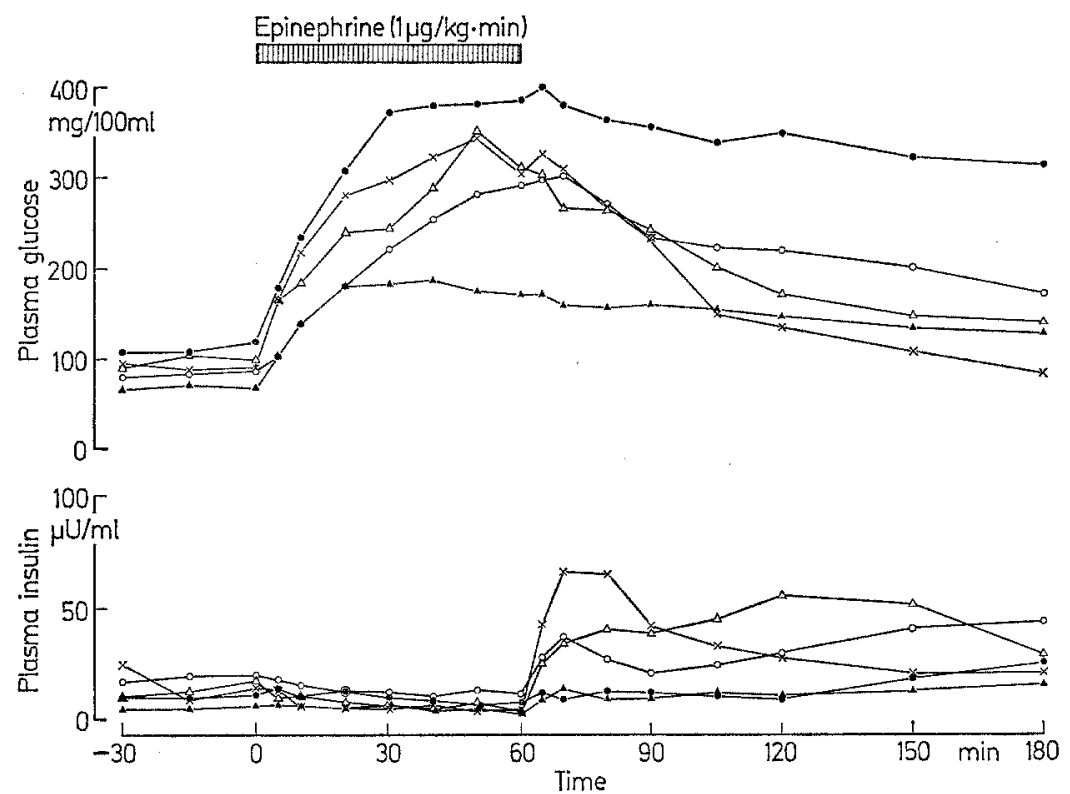

Fig. 5. Effect of infusion of epinephrine upon plasma glucose and insulin in 5 anaesthetized dogs. Epinephrine was infused intravenously at a rate of $1.0 \mu \mathrm{g} / \mathrm{kg} \cdot \mathrm{min}$ for $60 \mathrm{~min}$. Different symbols denote different dogs. Plasma insulin did not increase despite hyperglycaemia during epinephrine infusion. It rose promptly after the termination of infusion

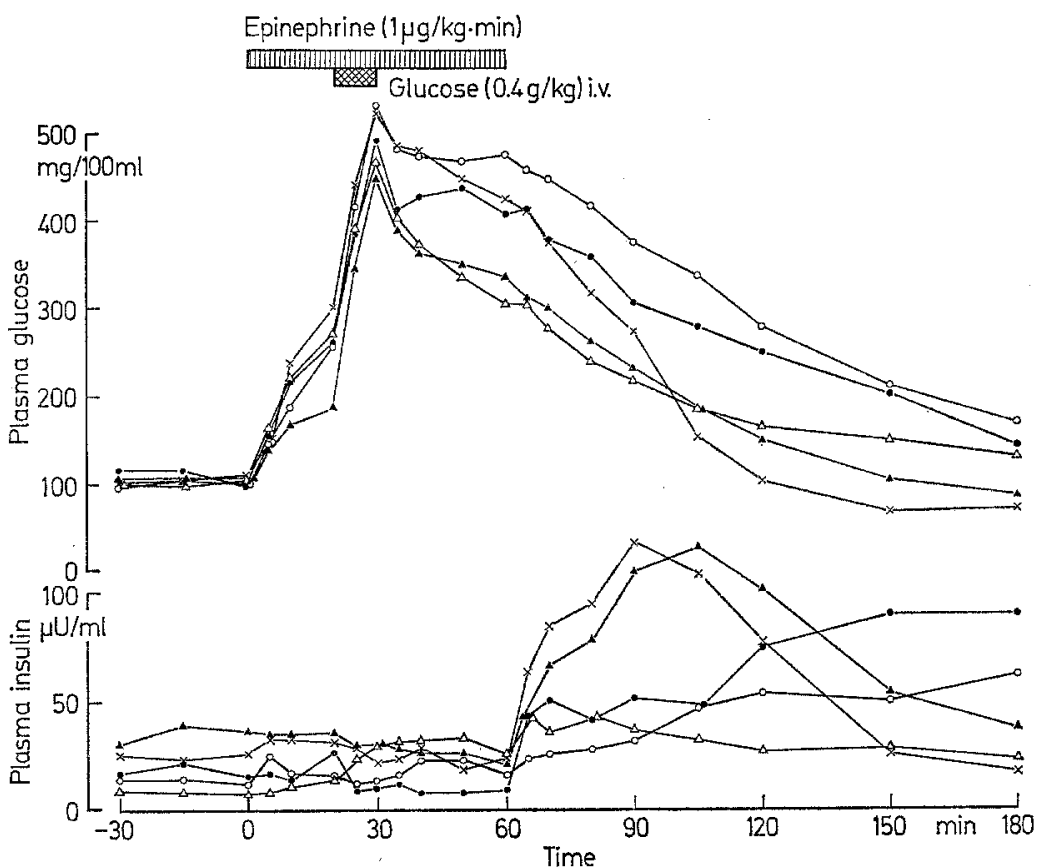

Fig. 6. Inhibition of glucose-induced insulin secretion by the infusion of epinephrine. Epinephrine was infused at $1.0 \mu \mathrm{g} / \mathrm{kg} \cdot \min$ for $60 \mathrm{~min}$. Glucose $(0.4 \mathrm{~g} / \mathrm{kg})$ was given intravenously over $10 \mathrm{~min}$ during epinephrine infusion. Plasma insulin did not increase significantly during the infusion of epinephrine, but rose promptly after the end of infusion. Different symbols denote different animals 


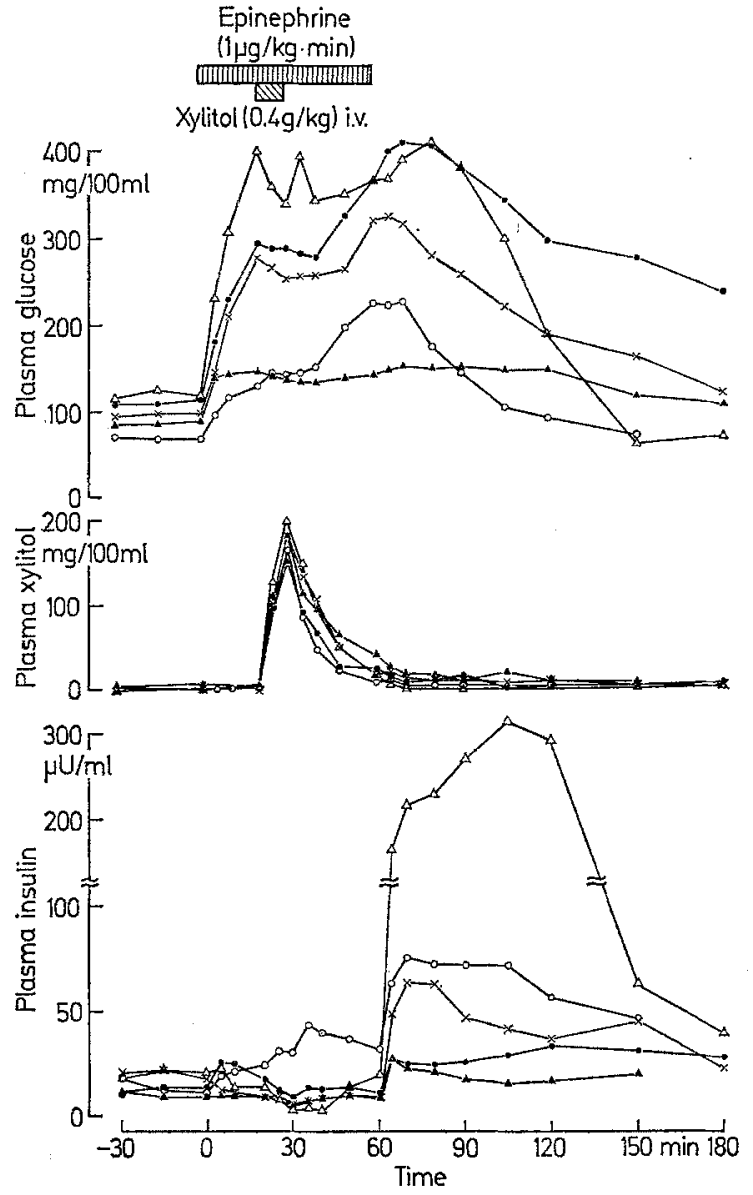

Fig. 7. Inhibition of xylitol-induced insulin secretion by the infusion of epinephrine. Epinephrine was infused intravenously at $1.0 \mathrm{\mu g} / \mathrm{kg} \cdot \mathrm{min}$ for $60 \mathrm{~min}$. Xylitol $(0.4 \mathrm{~g} / \mathrm{kg})$ was injected intravenously over $10 \mathrm{~min}$ during epinephrine infusion. Plasma insulin did not rise during the infusion of epinephrine. It increased promptly after the cessation of infusion. Different symbols denote different animals

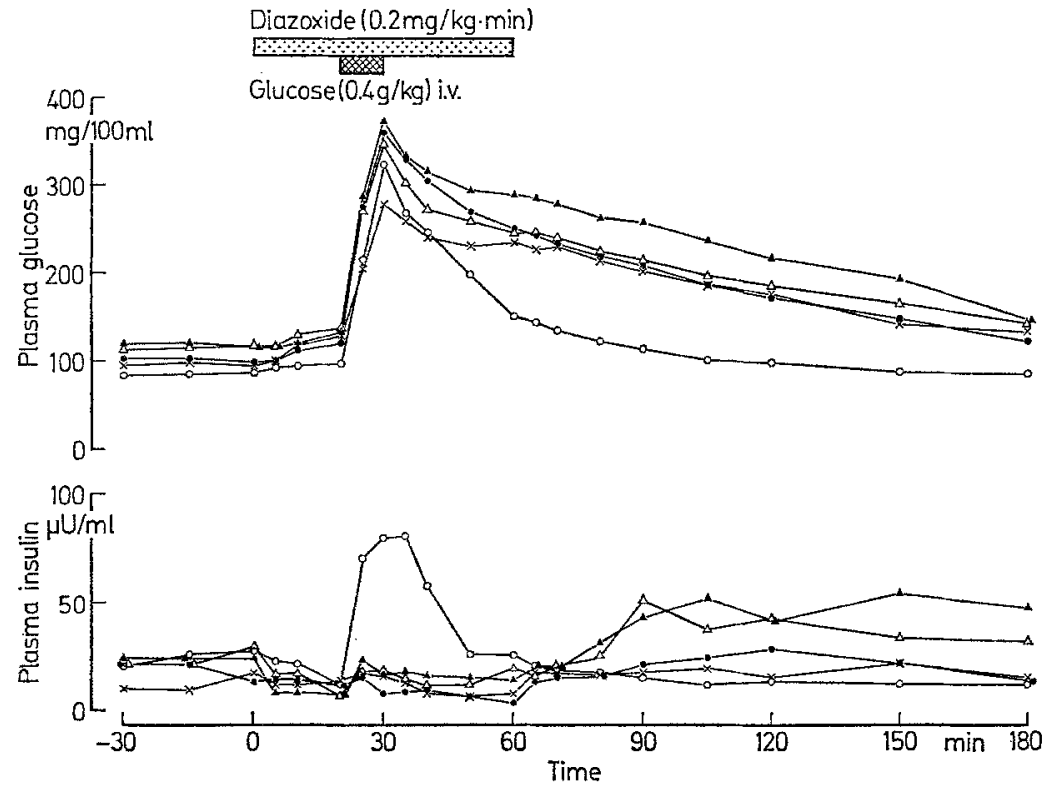

Fig. 8. Effect of the infusion of diazoxide upon glucose-induced insulin secretion. Diazoxide was infused at a rate of $0.2 \mathrm{mg} /$ $\mathrm{kg} \cdot \mathrm{min}$ for $60 \mathrm{~min}$. Glucose $(0.4 \mathrm{~g} / \mathrm{kg})$ was given intravenously during the infusion of diazoxide. Different symbols denote different animals. In 4 out of 5 dogs, the rise of plasma insulin following glucose loading appears to be suppressed by diazoxide infusion 
Plasma insulin did not rise at all in 3 dogs after xylitol injection, but it increased clearly in one dog. Plasma insulin tended to rise slightly following cessation of diazoxide infusion.

\section{Discussion}

Our previous studies [8, 9] showed that systemic administration of xylitol, particularly at high doses, caused a marked increase in plasma insulin in dogs, exceeding the hyperinsulinaemia resulting from equivalent doses of glucose. However, it was still uncertain whether this strong effect of xylitol resulted from its direct action upon the islets, or whether it was converted to a metabolite which in turn stimulated the secretion of insulin. In our present study, infusion of small doses of glucose or xylitol, which were almost totally ineffective by the systemic intravenous route, produced a marked increase in plasma insulin in the pancreatic vein when administered into the superior pancreaticoduodenal artery. When xylitol or glucose was infused into the superior pancreaticoduodenal artery and blood samples were taken both from the superior pancreaticoduodenal vein and the splenic vein, the clear increase in plasma insulin was observed only in the former vein, which drained the portion of the pancreas perfused by the superior pancreaticoduodenal artery. All these data support the direct local action of xylitol upon islets, although they do not necessarily mean that xylitol stimulates the beta cells directly, since it is still possible that alpha cells or other pancreatic cells, which are also exposed to a high concentration of xylitol during infusion, might release glucagon or another insulinotropic substance, thereby stimulating insulin secretion indirectly. However, the rapidity of the insulin-releasing response to xylitol infusion seems to favour the view that its main effect is the result of a direct action upon beta cells. This is in accord with the observation of MONTAGUE etal. [11], who reported that xylitol stimulated the release of insulin from isolated rat islets. Our data do not rule out the possiblity that some metabolite of xylitol may also be effective in stimulating insulin secretion. Although our impression is that the effect of xylitol did not exceed that of glucose when administered in the pancreatic artery, quantiative comparison of the insulinotropic effect of xylitol with that of glucose is very difficult in our local infusion experiments, because of the marked variations in the plasma levels of xylitol or glucose and of insulin in the pancreatic vein during the infusions. This variation is probably attributable mainly to the individual variation of the vascular system of the dog pancreas, which is perfused by several different arteries, and also to unavoidable, small changes in the position of the catheter tip. Variation in the relative contribution and blood flow of each vessel may lead to variable dilution of the infused substance.

Epinephrine and diazoxide are known to suppress the secretion of insulin both in vivo $[12,4]$ and in vitro $[11,3]$. In our experiments, inhibition of insulin release by epinephrine was observed in all cases, but the inhibitory effect of diazoxide was more variable for both glucose- and xylitol-mediated insulin response. Although the reason for this variability is unknown, it is possible that the effect of diazoxide is mediated not only by a direct action on the islet, but also by some indirect one mediated by adrenergic hormones [6]; thus the mechanism of its inhibition of insulin release in vivo may be more complex than that of epinephrine.

Among various insulin-releasing substances, the effect of arginine is not suppressed either by epinephrine or by diazoxide $[2,13]$, and the inhibitory effect of diazoxide upon insulin secretion is reported to be counteracted by tolbutamide $[3,10]$. In this respect, the insulinotropic effect of xylitol appears similar to that of glucose rather than to that of arginine or sulphonylureas. The present data may suggest the possibility that the insulin-releasing actions of glucose and xylitol share some common mechanism.

Acknowledgements. We are grateful to Professor KikU Nakao for his support during this study, and to Professor Albert E. Renom for his kind oriticism of the manuscript. Skillful technical assistance of Mr. SHTGERU NAGAYAMA is much appreciated. We are also indebted for the generous supply of xylitol, to Eisai and Co., 4-chome, Koishikawa, Bunkyo-ku, Tokyo, Japan. Diazoxide was kindly donated by the Schering Corporation, Bloomfield, New Jersey, U.S.A.

\section{References}

1. Burton, R.M., In: S.P. Colowick, and N.O. KaPLAN (eds.): Method in Enzymology, Vol. III, p. 246. New York: Academic Press 1957.

2. FaJans, S.S., J.C. Floyd, JR., R.F. KNopF, and J.W. CONN : Effect of amino acids and proteins on insulin secretion in man. Recent Progr. Hormone Res. 23, 617-662 (1967).

3. Frerichs H., R. Gerber, und W. Creutsfeld : Insulinsekretion in vitro. II. Hemmung der glukoseinduzierten Insulinabgabe durch Diazoxide. Diabetologia 2, 269-276 (1966).

4. Graber, A.L., D. Porte, JR., and R.H. Williams: Clinical use of diazoxide and mechanism for its hyperglycemic effects. Diabetes 15, 143-148 (1966).

5. Hrrata, Y., M. Fujisawa, H. Sato, T. Asano, and S. KatsukI: Blood glucose and plasma insulin responses to xylitol administrated intravenously in dogs. Biochem. biophys. Res. Commun. 24, 471-475 (1966).

6. JANES, R.G., R.J. RowLF, and W.R. WILson: Effect of guanethidine and adrenal demedullation on hyperglycemic responses to diazoxide in rats. Proc. Soc. expl. Biol. (N.Y.) 117, 572-575 (1964).

7. Kanazawa, Y., T. KuzuYa, T. Ide, and K. Kosaka: Plasma insulin responses to glucose in femoral, hepatic, and pancreatic veins in dogs. Amer. J. Physiol. 211, 442-448 (1966).

8. KuzuYa, T., Y. Kanazawa, and K. KosaKa: Plasma insulin response to intravenously administered xylitol in dogs. Motabolism 15, 1149 - 1152 (1966).

9. - - M. Shimoshige, and K. KosaKa: Stimulation of insulin secretion by xylitol in dog and in man. Excerpta Medica International Congress Series No. 140, 77 (1967). 
10. Loubatimeres, A., M.M. Mariani, R. Alric et J. ChaPad : Antagonisme du tolbutamide et du diazoxide sur l'insulino-sécrétion. Excerpta Medica International Congress Series No. 140, 79 (1967).

11. Montague, W., S.L. Howeli, and K.W. Taylor Pentitols and the mechanism of insulin release. Nature 215, 1088-1089 (1967).

12. Ponte, K. Jr., A.L. Graber, T. Kuzuya, and R.H. Williams: The effect of epinephrine on immunoreactive insulin levels in man. $J$. clin. Invest. 45 , $228-236(1966)$.
13. RaBinowitz: In discussion of the article by S.S. Fajans et al. [2]. Recent Progr. Hormone Res. 28, $656(1967)$.

14. Somogy, M.: Determination of blood sugar. J. biol. Chem. 160, 69-73 (1945).

Takeshi KuzuYa, M.D.

The Third Department

of Internal Medicine

Faculty of Medicine

University of Tokyo

Hongo, Tokyo, Japan 